Saudi Journal of Medical and Pharmaceutical Sciences

Abbreviated Key Title: Saudi J Med Pharm Sci

ISSN 2413-4929 (Print) |ISSN 2413-4910 (Online)

Scholars Middle East Publishers, Dubai, United Arab Emirates

Journal homepage: http://scholarsmepub.com/sjmps/

Original Research Article

\title{
Iron Status in Sickle Cell Disease and Trait: A Report from Jharkhand of Eastern India
}

Nitish Kumar ${ }^{1}$, Sandip Sen ${ }^{2 *}$

${ }^{1}$ Assistant Professor, Dept of Pediatrics,North Bengal Medical College, PO-Sushrut Nagar, Darjeeling, West Bengal, India

${ }^{2}$ Associate Professor, Dept of Pediatrics, Dr. B. C. Roy Post Graduate Institute of Paediatric Sciences, PO-Kankurgachi, Kolkata, West Bengal, India

$\begin{array}{ll}\text { DOI: } 10.36348 / \text { sjmps.2019.v05i12.013 } & \text { | Received: 01.12.2019| Accepted: 08.12.2019| Published: } 26.12 .2019\end{array}$

*Corresponding author: Sandip Sen

Abstract

Objective: To assess the iron status in children with sickle cell disease (SCD) and trait (SCT). Design: Prospective, observational, descriptive study. Setting: Referral tertiary hospital in the state of Jharkhand. Methods: 108 consecutive patients of SCD and trait were enrolled and complete hemogram, serum iron and serum ferritin were measured. Results: Patients with SCT were more at risk of having iron deficiency (ID) than SCD.ID was present in patients who had not received or received $<5$ units of blood transfusion (BT).High iron level was found in all the patients who had received more than 10 units of BT. Serum Ferritin level had linear relationship with units of BT. Conclusion: Patients with SCT were more in number than that of homozygous SCD (2.6:1). Patients with SCT had more chances to have ID than homozygous SCD.

Keywords: Sickle cell disease, Sickle cell trait, Serum Iron.

Copyright @ 2019: This is an open-access article distributed under the terms of the Creative Commons Attribution license which permits unrestricted use, distribution, and reproduction in any medium for non-commercial use (NonCommercial, or CC-BY-NC) provided the original author and source are credited.

\section{INTRODUCTION}

Sickle cell disease (SCD) is the result of a single base pair change at the 6th codon of the $\beta$-gene causing replacement of glutamine by valine. It leads to polymerization of hemoglobin under hypoxia and consequent destruction of red blood corpuscles (RBC). About 50\% of world populations of SCD cases are found in India [1]. Estimates indicate that sickle cell trait (SCT) is predominant among the tribal population of central India [2,3]. Incidence of SCD is 3.3\% in tribal children of Chotanagpur (Jharkhand) which ranges from $0 \%$ to $10 \%$ in various parts of the state [4]. It is the melting pot of Arab Indian (AI) and East Asian (EA) haplotypes [4]. The predominant population of the newly formed state of Jharkhand, is tribal. Iron status of children in SCD from India is not studied adequately.

\section{AIMS AND OBJECTIVES}

- To study iron status in children with SCD and trait.

- To estimate iron status following blood transfusion.

\section{MATERIAL AND METHOD}

This was a prospective and descriptive study. One hundred and eight consecutive children suffering from SCD and trait, between the ages of 3-18 years attending outpatient department (OPD) and admitted in pediatric ward of Rajendra Institute of Medical Sciences (RIMS), Ranchi, Jharkhand, from September 2008 to September 2010 were selected. Those patients with double heterozygous conditions like SC disease, sickle $\beta$ thalassaemia and others as proved by hemoglobin electrophoresis and those on iron chelation therapy were excluded from the study.

Nutritional status was assessed in all cases by weight for age, height for age and weight for height and comparing with age and sex specific WHO growth charts. Patients with weight for height and height for age less than 2 Standard Deviation (SD) had been considered as malnutrition. All children were evaluated by hematological profile including hemoglobin, total leukocyte count, differential leukocyte count, total RBC count, reticulocyte count, mean corpuscular hemoglobin, mean corpuscular volume, mean corpuscular hemoglobin concentration. Iron profiles of those patients including serum iron $(\mu \mathrm{g} / \mathrm{dL})$ and serum ferritin $(\eta \mathrm{g} / \mathrm{ml})$ were estimated. Stool sample of all the children were examined for ova, parasite and presence of occult blood. 
Cases having haemoglobin $\mathrm{S}(\mathrm{HbS})>50 \%$ of total haemoglobin were defined as SCD, those with $\mathrm{HbS}<50 \%$ as SCT [5].

Normal serum iron and ferritin level were considerd to be 22-184 $\mu \mathrm{g} / \mathrm{dL}$ and $7-140 \mu \mathrm{g} / \mathrm{ml}$ respectively [6].

\section{RESULTS}

One hundred and eight (108) consecutive SCD and trait were enrolled in the study. Out of 108 patients sixty six $(61.1 \%)$ were boys and forty two $(38.9 \%)$ girls.

Table-1: Demographic profile of patients

\begin{tabular}{|l|l|l|l|l|l|l|}
\hline Race & M & F & Age $<\mathbf{1 0}$ years & Age $>\mathbf{1 0}$ years & Total & Percentage \\
\hline Tribal & 48 & 30 & 35 & 43 & 78 & $72.2 \%$ \\
\hline Non tribal & 18 & 12 & 14 & 16 & 30 & $27.8 \%$ \\
\hline & 66 & 42 & 49 & 59 & 108 & \\
\hline
\end{tabular}

In this study tribal children dominated the group (78/108). Children below age of 10 years were $45.4 \%(49 / 108)$ while $M: F$ ratio in this cohort was 1.57:1.
Among the study population seventy eight $(72.2 \%)$ children were having sickle cell trait and thirty $(27.8 \%)$ with SCD.

Table-2: Showing distribution of serum iron \& serum ferritin level in patients with Sickle cell traits and SCD

\begin{tabular}{|l|l|l|}
\hline Serum Iron \& Ferritin level & Sickle cell traits (\%) & SCD (\%) \\
\hline Normal level & $42(53.84 \%)$ & $15(50 \%)$ \\
\hline Low level & $24(30.76 \%)$ & $3(10 \%)$ \\
\hline High level & $12(15.38 \%)$ & $12(40 \%)$ \\
\hline
\end{tabular}

Serum Iron level in SCT varied from 8.8-226 $\mu \mathrm{g} / \mathrm{dL}$, with mean of $67.37 \mu \mathrm{g} / \mathrm{dL}$, whereas in SCD the range was from $12-221 \mu \mathrm{g} / \mathrm{dL}$, with mean of $112.8 \mu \mathrm{g} / \mathrm{dL}$. Serum ferritin level in SCT varied from $4.7-450 \eta \mathrm{g} / \mathrm{ml}$; mean $79.6 \eta \mathrm{g} / \mathrm{ml}$ and in SCD varied from 4.8-380 $\eta \mathrm{g} / \mathrm{ml}$; mean $140.2 \eta \mathrm{g} / \mathrm{ml}$.

Twenty seven (27) patents had low level of serum ferritin and serum iron, fifty seven (57) had normal level and twenty four (24) patients had high level of serum iron and ferritin. Out of twenty seven (27) patients with low level of serum iron and ferritin, twenty four (24) were tribal. Applying the chi-square test between SCT and homozygous SCD with $1^{\text {st }}$ degree freedom, the observed value was $1.809(\mathrm{p}<0.05)$. Hence we concluded that patients with SCT had more chances to have iron deficiency than homozygous SCD.

Malnutrition was observed in sixty seven patients of SCT $(85.9 \%)$ and twenty eight patients of $\operatorname{SCD}(93.33 \%)$.

Iron status between transfused and nontransfused children is discussed in the following Table3.

Table-3: Iron status in relation to Blood Transfusion (BT)

\begin{tabular}{|l|l|l|l|l|}
\hline Units of blood & Total no. of patients & Normal Iron status (\%) & Low Iron status (\%) & High Iron status (\%) \\
\hline Nil & 21 & $15(71.42 \%)$ & $6(28.57 \%)$ & 0 \\
\hline $1-4$ & 36 & $15(41.66 \%)$ & $21(58.33 \%)$ & 0 \\
\hline $5-10$ & 18 & $18(100 \%)$ & 0 & 0 \\
\hline $11-15$ & 15 & $9(60 \%)$ & 0 & $6(40 \%)$ \\
\hline $16-20$ & 6 & 0 & 0 & $6(100 \%)$ \\
\hline $21-25$ & 6 & 0 & 0 & $6(100 \%)$ \\
\hline $26-30$ & 6 & 0 & 0 & $6(100 \%)$ \\
\hline
\end{tabular}

Those who were transfused with more than ten units of blood had serum iron level between 80- 226 $\mu \mathrm{g} / \mathrm{dL}$ (mean $141.5 \mu \mathrm{g} / \mathrm{dL}$ ) and ferritin level 120-450 $\eta \mathrm{g} / \mathrm{ml}$ (mean $256.8 \eta \mathrm{g} / \mathrm{ml}$ ).

A fairly linear relationship was observed between amount of BT and serum ferritin level. Though these patients had high iron and ferritin level, serum ferritin level was always below $1000 \mathrm{\eta g} / \mathrm{ml}$.

\section{DISCUSSION}

This study was conducted at RIMS Ranchi, located in the region where SCD and trait is prevalent. $72.2 \%$ of our study group belonged to tribal community. Burn HF et al., [2] and Balgir RS et al., [3] also observed that SCT is predominant among the tribal population of India. 
We observed that sixty seven patients of SCT $(85.9 \%)$ and twenty eight patients of SCD $(93.33 \%)$ had malnutrition. So malnutrition was a risk factor for IDA. Our study is comparable with studies by Prasad R K et al., [7], Raghupathy R et al., [8], King L et al., [9], Rao et al., [10] and Vichinsky et al., [11].

Chronic haemolysis, increased absorption of iron from gastrointestinal tract as well as iron provided by blood transfusion would suggest that Iron Deficiency (ID) is unlikely in SCD [12-14]. But ID had been described in pediatric population with SCD both due to nutritional status and intravascular haemolysis with urinary iron losses [14].

Study by Das et al., [15] in Orissa found malnutrition and worm infestation as the commonest cause behind ID in children of SCD and trait. But in another study Haddy et al., [16] found that overt ID in SCD and trait was due to suspected blood loss.

Our study as well as study by L. King et al., [13] indicated that iron deficiency was more common among SCT than SCD, which is statistically significant.

High iron status was observed in $40 \%$ of SCD and $15.38 \%$ of SCT in our study. Hussain et al., [17] observed that $86 \%$ of SCD had ferritin level greater than $101 \eta \mathrm{g} / \mathrm{ml}$. Serjeant et al., [18] had reported the higher serum iron level in SCD than control. The probable reason is the excessive intravascular haemolysis as well as increased blood transfusion in SCD. In present study it was found that there were some correlations between blood transfusion (BT) and serum ferritin. High iron status was found only in children who needed frequent BT. But according to our study, none of our patients had serum iron more than $1000 \eta \mathrm{g} / \mathrm{ml}$. Das et al., [15] found the same result in his study. In another study on effect of BT on iron status in SCD and trait by Davis et al., [19] found that the serum ferritin was lower than normal in patients who were not transfused. Hussain MA et al., [17] observed that $6 \%$ of SCD had ferritin level greater than $1000 \eta \mathrm{g} / \mathrm{ml}$. Vichinsky et al., [20] described 43 adult patients with SCD who were previously transfused for a mean of 6 years, resulting in elevated mean ferritin levels at 2916 $\mathrm{ng} / \mathrm{mL}$. But patients under our study never required chelation therapy, as serum ferritin level was always below $1000 \mathrm{ng} / \mathrm{mL}$. Probable reason is that all the patients in our study were of pediatric age group and a significant proportion of our patients had moderate to severe malnutrition.

Jenkins et al., [21] has suggested that iron regulatory proteins, hepcidin and ferritin could undergo changes in the setting of post-transfusional hemosiderosis.
A large study by Mohanty et al., [22] involving 8434 individuals with sixty seven per cent of subjects with sickle cell anaemia and 26 per cent with sickle cell trait having elevated $\mathrm{ZPP} / \mathrm{H}$ ratios $(>80$ micromol $/ \mathrm{mol}$ ) as against 22.8 per cent of normal individuals. The elevated $\mathrm{ZPP} / \mathrm{H}$ ratios is an indicator of microcytic anaemia of iron deficiency. Following iron therapy for 12 weeks and repetition of laboratory investigations at 13 weeks, an improvement in the $\mathrm{Hb}$ levels and $\mathrm{ZPP} / \mathrm{H}$ (zinc protoporphyrin/haem) ratios was observed in both sickle cell disorders and normal individual cases. This study suggests that iron deficiency anaemia is an important problem in Indian sickle cell anaemia patients and iron supplementation should be given only in proven cases of iron deficiency anaemia.

\section{CONCLUSION}

Sickle cell diseases as well as sickle cell trait are common in the tribal population of Jharkhand. Patients with sickle cell trait were more than that of homozygous SCD (2.6:1).

Patients with sickle cell trait had more chances to have iron deficiency than homozygous SCD. Iron deficiency was found in those who were not transfused or transfused with $<5$ units of blood.

All the patients who required transfusion with more than 15 units of blood had high serum iron and ferritin level.

Limitation of the Study: Single centre study.

Conflict of Interest: None stated.

\section{Source of Funding: None.}

Ethical approval: The study was approved by the Institutional Ethics Committee and Institutional Scientific Committee.

Author's contribution; NK and SS were involved in diagnosis and management of the patients. SS and NK searched the literature. SS and NK drafted the manuscript. NK and SS did the critical review. Both the authors approved the final version.

\section{REFERENCES}

1. Mohanty, D., \& Pathare, A. V. (1998). Sickle cell Anemia-the Indian scenario. Indian J. Hematol Blood Transfus, 16(1-1), 1-2.

2. Bunn, H. F. (1997). Pathogenesis and treatment of sickle cell disease. New England Journal of Medicine, 337(11), 762-769.

3. Colah, R. B., Mukherjee, M. B., Martin, S., \& Ghosh, K. (2015). Sickle cell disease in tribal populations in India. The Indian journal of medical research, 141(5), 509-515. 
4. Nagar, R., \& Raman, R. (2015). Diversity of sickle cell trait in Jharkhand state in India: Is it the zone of contact between two geographically and ethnically distinct populations in India?. Journal of biosciences, 40(3), 539-547.

5. Smith-Whitley, K., \& Kwiatkowski, J. L. Hemoglobinopathies. In Kliegman R. M., St Geme III, J. W., Blum, N. J., Shah, S. S., Tasker R. C., \& Wilson K. M., editors. Nelson Textbook of Pediatrics Vol 2; $21^{\text {st }}$ Edition Philadelphia: Elsevier; 2020, 2541-2550

6. Lo, S. F. Reference intervals for laboratory tests and procedures. In Kliegman, R. M., St Geme III, J. W., Blum, N. J., Shah, S. S., Tasker, R. C., Wilson, K. M., editors, Nelson Textbook of Pediatrics Vol 2; $21^{\text {st }}$ Edition Philadelphia: Elsevier; 2020:e5

7. Koduri, P. R. (2003). Iron in sickle cell disease: a review why less is better. American journal of hematology, 73(1), 59-63.

8. Raghupathy, R., Manwani, D., \& Little, J. A. (2010). Iron overload in sickle cell disease. Advances in hematology, 2010.

9. King, L., Reid, M., \& Forrester, T. E. (2005). Iron deficiency anaemia in Jamaican children, aged 1-5 years, with sickle cell disease. West indian medical journal, 54(5), 292-296.

10. Rao, J. N., \& Sur, A. M. (1980). Iron deficiency in sickle cell disease. Acta Padiatrica, 69(3), 337340 .

11. Vichinsky, E., Kleman, K., Embury, S., \& Lubin, B. (1981). The diagnosis of iron deficiency anemia in sickle cell disease. Blood, 58(5), 963-968.

12. Erlandson, M. E., Walden, B., Stern, G., Hillgartner, M. W., Wehman, J., \& Smith, C. H. (1962). Studies on Congenital Hemolytic Syndromes. IV. Gastrointestinal Absorption of Iron. Blood, J. Hematol., 19(3), 359-78.

13. O'Brien, R. T. (1978). Iron burden in sickle cell anemia. The Journal of pediatrics, 92(4), 579-582.

14. Ballas, S. K. (2001, January). Iron overload is a determinant of morbidity and mortality in adult patients with sickle cell disease. In Seminars in hematology, 38:30-36.

15. Das, P. K., Sarangi, A., Satapathy, M., \& Palit, S. K. (1990). Iron in sickle cell disease. Journal Assoc Physicians India, 38:847-849.

16. Haddy, T. B., \& Castro, O. (1982). Overt iron deficiency in sickle cell disease. Archives of internal medicine, 142(9), 1621-1624.

17. Hussain, M. A., Davis, L. R., Laulicht, M., \& Hoffbrand, A. V. (1978). Value of serum ferritin estimation in sickle cell anaemia. Archives of disease in childhood, 53(4), 319-321.

18. Serjeant, G. R., Grandison, Y., Lowrie, Y., Mason, K., Phillips, J., Serjeant, B. E., \& Vaidya, S. (1981). The development of haematological changes in homozygous sickle cell disease: a cohort study from birth to 6 years. British journal of haematology, 48(4), 533-543.

19. Davies, S., Henthorn, J. S., Win, A. A., \& Brozovic, M. (1982). Effect of blood transfusion on iron status in sickle cell anemia. Arch Intern Med, 142:1621-1624.

20. Vichinsky, E., Butensky, E., Fung, E., Hudes, M., Theil, E., Ferrell, L., ... \& Harmatz, P. (2005). Comparison of organ dysfunction in transfused patients with SCD or $\beta$ thalassemia. American journal of hematology, 80(1), 70-74.

21. Jenkins, Z. A., Hagar, W., Bowlus, C. L., Johansson, H. E., Harmatz, P., Vichinsky, E. P., \& Theil, E. C. (2007). Iron homeostasis during transfusional iron overload in $\beta$-thalassemia and sickle cell disease: changes in iron regulatory protein, hepcidin, and ferritin expression. Pediatric hematology and oncology, 24(4), 237-243.

22. Mohanty, D., Mukherjee, M. B., Colah, R. B., Wadia, M., Ghosh, K., Chottray, G. P., ... \& Shukla, D. K. (2008). Iron deficiency anaemia in sickle cell disorders in India. Indian Journal of Medical Research, 127(4):366-369. 